\title{
REHABILITATION GROUP: BENEFITS AND BARRIERS IN THE PERSPECTIVE OF WOMEN WITH BREAST CANCER ${ }^{1}$
}

\author{
Edilaine Assunção Caetano de Loyola², Mariana Lopes Borges ${ }^{3}$, Paola Alexandria Pinto de Magalhães ${ }^{4}$, Felipe \\ de Souza Areco ${ }^{5}$, Leonardo Toshiaki Borges Yochimochi ${ }^{6}$, Marislei Sanches Panobianco ${ }^{7}$
}

${ }^{1}$ Text extracted from dissertation - Participação de mastectomizadas em um grupo de reabilitação: benefícios e barreiras percebidos, presented to the Programa de Pós-Graduação Enfermagem em Saúde Pública in the Escola de Enfermagem de Ribeirão Preto (EERP) in the Universidade de São Paulo (USP), in 2012.

${ }^{2}$ Coctoral student, Programa de Pós-Graduação Enfermagem em Saúde Pública. EERP/USP. Ribeirão Preto, São Paulo, Brasil. E-mail: edilainecaetano@usp.br

${ }^{3}$ Master's student, Programa de Pós-Graduação Enfermagem em Saúde Pública, EERP/USP. Ribeirão Preto, São Paulo, Brazil. E-mail: malibel01@gmail.com

${ }^{4}$ Doctoral student, in the Pós-Graduação Enfermagem em Saúde Pública, EERP/USP. Ribeirão Preto, São Paulo, Brazil. E-mail: paolaalexandria@yahoo.com.br

${ }^{5}$ Master's student, Pós-Graduação Enfermagem em Saúde Pública, EERP/USP. Ribeirão Preto, São Paulo, Brasil. E-mail: felipearecopsicologo@gmail.com

${ }^{6}$ Master's student, Programa de Pós-Graduação Enfermagem em Saúde Pública, EERP/USP. Ribeirão Preto, São Paulo, Brazil. E-mail: leoborges.psi@gmail.com

7 Ph.D. in Nursing. Professor Departamento de Enfermagem Materno-Infantil e Saúde Pública, EERP/USP. Ribeirão Preto, São Paulo, Brazil. E-mail: marislei@eerp.usp.br

\section{ABSTRACT \\ Objective: to analyze the perceptions of women with breast cancer about the benefits and barriers to the participation in rehabilitation groups, according to the Health Belief Model. \\ Method: a descriptive study with qualitative approach, conducted in 2011. Participants were eight women, aged from 54 to 67 years, after surgery for breast cancer, and members of a rehabilitation group. Data was collected through semi-structured interviews and focus groups. thematic Content analysis of the data was performed. \\ Results: perceived benefits: physical improvement with possibility to return to daily activities; bond with multidisciplinary team; psychological support; opportunity to share experiences, clarify doubts and feel like "equals" Perceived barriers: appointment day and time; physical space; housework; time consuming and disposal. \\ Conclusion: women saw benefits of having a preventive health behavior; however, they recognized significant barriers that must be faced in the rehabilitation process. \\ DESCRIPTORS: Breast neoplasms. Nursing. Rehabilitation. Oncology nursing. \\ GRUPO DE REABILITAÇÃO: BENEFÍCIOS E BARREIRAS SOB A ÓTICA DE MULHERES COM CÂNCER DE MAMA}

RESUMO

Objetivo: analisar as percepções de mulheres com câncer de mama sobre os benefícios e as barreiras para a participação em grupos de reabilitação, à luz do Modelo de Crenças em Saúde.

Método: estudo descritivo com abordagem qualitativa, realizado em 2011. Participaram oito mulheres, entre 54 e 67 anos, pós-cirurgia de câncer de mama, integrantes de um grupo de reabilitação, por meio de grupos focais e de entrevistas semiestruturadas realizada análise de conteúdo temática dos dados.

Resultados: benefícios percebidos: melhora física com possibilidade de retorno às atividades diárias; vínculo com equipe multidisciplinar; apoio psicológico; oportunidade de compartilhar experiências, sanar dúvidas e se sentir em meio a "iguais". Barreiras percebidas: dias e horários de atendimentos; espaço físico; afazeres domésticos; necessidade de demandar tempo e disposição.

Conclusão: as mulheres vislumbraram benefícios para a tomada de ação de um comportamento preventivo em saúde, porém reconheceram barreiras significativas que devem ser trabalhadas na reabilitação.

DESCRITORES: Neoplasias da mama. Enfermagem. Reabilitação. Enfermagem oncológica. 


\section{GRUPO DE REHABILITACIÓN: BENEFICIOS Y BARRERAS EN LA PERSPECTIVA DE MUJERES CON CÁNCER DE MAMA}

\section{RESUMEN}

Objetivo: analizar las percepciones de mujeres con cáncer de mama con relación a los beneficios y barreras en la participación en grupos de rehabilitación a la luz del Modelo de Creencias en Salud.

Método: estudio descriptivo, cualitativo, realizado en 2011. Los participantes fueron ocho mujeres entre 54 y 67 años, post-quirúrgicas al cáncer de mama, y miembros de un grupo de rehabilitación. Para la recolección de datos se utilizaron grupos focales y entrevistas semiestructuradas el análisis de contenido temático fue realizado.

Resultados: beneficios percibidos: mejoramiento físico con posibilidad de regreso a las actividades diarias; vínculo con equipo multidisciplinario; apoyo psicológico; oportunidad de compartir experiencias, sacar dudas y sentirse "iguales". Barreras percibidas: días y horarios de atención; espacio físico; tareas del hogar; consumo de tiempo y disposición.

Conclusión: las mujeres identifican beneficios para la adopción de una conducta de salud preventiva, pero reconocen barreras que deben ser trabajadas en la rehabilitación.

DESCRIPTORES: Neoplasias de la mama. Enfermería. Rehabilitación. Enfermería oncológica.

\section{INTRODUCTION}

Breast cancer is the most common cancer among women worldwide. In conjunction with improvements in therapy, the survival rate has increased. However, traditional therapies such as chemotherapy, radiation therapy, and hormone therapy have undesirable adverse events such as nausea, vomiting, loss of appetite, changes in weight, fatigue, among others. ${ }^{1}$ Surgery, sometimes mutilating, can cause several complications, which can include lymphedema and limiting the movements of the ipsilateral arm, affecting the activities of daily living, ${ }^{1-2}$ as well as bodily changes that are often traumatic for women, leading to emotional compromise. ${ }^{2}$ Therefore, patients with breast cancer undergo major changes in their lives and in their social roles, and require support to adapt to their new condition.

Among the types of support, examples such as religiousness/spirituality, family and social support can be cited. The latter is understood as a moment of integration of people or groups, aiming at reciprocal aid among members, resulting in benefits for personal and group well-being, improving the psychosocial aspect in the health-disease process. ${ }^{3}$ In oncology, rehabilitation is considered part of the care and support to individuals affected by the disease and should be available at all stages, from diagnosis and even during treatment, to incorporate the survivors and their arising condition of increased life expectancy. ${ }^{4}$

Rehabilitation is defined as an interdisciplinary process, an integrated, coordinated, individualized approach, focused on the exploration of the global potential of the individual, considering the physical, psychological, social and occupational dimensions, respecting their limitations, so a higher degree of personal independence can be achieved and therefore social reintegration. ${ }^{5}$
With regard to breast cancer, there is a shortage of specialized rehabilitation services in the country. In view of this, the rehabilitation groups emanated as a possibility to meet the demands of women with the disease. These groups are defined as areas in which the individual receives professional and appropriate multidisciplinary support, with the ultimate goal of reaching the maximum range of their physical and psychosocial functionality in an integrated perspective. ${ }^{6}$ Assistance given to the same, allows aspects which are not routinely observed by team health to be better dealt with, presenting better results. ${ }^{7}$

So there are a number of factors that can lead women diagnosed with breast cancer to participate in a rehabilitation group, standing out among them is the exchange of experiences related to treatment, the reception of participants and professionals, necessary information for the understanding of breast cancer and the treatment and the bond of affection established between the participants. ${ }^{8}$

However, barriers to group participation can also be verified as the lack of adequate physical infrastructure services for the development of activities, the number of days and limited service hours, lack of willpower and women's time to adhere to the guidelines, the undesirable effects of anticancer treatments and family responsibilities. ${ }^{9}$

Therefore, for successful rehabilitation, the satisfactory adherence of women to undertake activities in the group and in the process is necessary, in this process the nurse plays an important role by participating in the therapeutic care and teamwork. Their actions are directed to favoring recovery and adaptation to the limitations imposed by the disease and to meet the needs of each patient and family, providing the opportunity for the individual to be the protagonist of his 
rehabilitation process. ${ }^{5}$

However, to support nursing practice, there is a shortage of works addressing the theme in the Brazilian context, as recently published literature review, ${ }^{7}$ making it necessary to develop new research. The author's experience in the professional practice, in the care of women with breast cancer led to this study, therefore, in exercised caution, it was observed that such patients may be subject to doubts, uncertainties and insecurities, which can intervene in their recovery. Exploring these aspects becomes significant, as they can serve for the development of strategies to minimize the trauma of the diagnosis and treatment of the disease, which are likely to occur.

Given the above, some questions were raised: why do women who have undergone treatment for breast cancer seek rehabilitation groups? What are the factors that motivate or discourage frequenting them and what are the advantages and constraints of attendance at such services?

In view of these, the aim of this study was to analyze the perceptions of women with breast cancer about the benefits and barriers to the participation of rehabilitation groups.

The theoretical framework adopted was the Health Belief Model that seeks to explain human behavior in relation to health and, in particular, responses and behaviors of individuals with symptoms, illness and, in particular, adherence to medical recommendations. ${ }^{10-11}$ the drafters of the Health Belief Model were influenced by the theories of Kurt Lewin, whose foundations are guided in the understanding that the world of the perceiver is what generates his actions, and not the physical environment that determines it, although it has a significant role, but only in the way it is represented in the mind of individual. ${ }^{11}$

The Health Belief Model includes four dimensions: perceived susceptibility, defined as the visualization of existing risks of presenting a particular health problem to the individual; the perceived seriousness, in which the subject may or may not consider that the pathology has potentially serious consequences; the benefits perceived by the individual to believe that preventive actions will cause positive results; and perceived barriers, dimension in which people consider that there are difficulties in adopting preventive measures. Individuals who assess the barriers can be overcome by the benefits and are more likely to show healthy behaviors. ${ }^{10-11}$ This study include two dimensions of Health Belief Model the benefits and perceived barriers.

According to the Health Belief Model, there are important psychological barriers, which are able to prevent the individual from taking actions related to disease prevention or reduction of vulnerabilities and the benefits are evaluated in terms of the barriers to realizing them. ${ }^{11}$

When dealing with perceived barriers, according to the Health Belief Model, there is a cost-effective evaluation of the negative aspects of the action; that is, an individual may believe that a certain action will be effective in reducing the threat of disease, but considers that it is not convenient or even possible, due to spending time, being considered unpleasant or potentially painful. These negative aspects of health problems serve as the adoption of healthy behaviors and cause conflicts. ${ }^{11}$ In this sense, the greater the perceived benefits to the adoption of a particular health action and the smaller the barriers, the greater the chances of adherence to that action by the individual. ${ }^{10}$

\section{METHOD}

A descriptive study with qualitative approach was perfomed with members of a rehabilitation group for women with breast cancer, linked to a public university of Minas Gerais.

The rehabilitation group started its activities in 2006, coordinated by a nurse, a university teacher; also including a physiotherapy service. The service aims to guide the stages of treatment and self-care with the ipsilateral arm surgery; encourage exercises; offer treatment for lymphedema; and guide self-massage for lymphatic drainage. Also, it aims to promote a space to answer questions and encourage socialization among the participants.

The meetings take place once a week, in the afternoon, with an average duration of two hours, and, the first time that a woman attends the service, her history of present illness and co-morbidities, identification data, surgery, adjuvant treatment and recorded perimetry arms are recorded and put in a file.

At the beginning of the service, there is group exercise for the women with less functional impairments and individuals, for beginners or those with complications such as lymphedema. Lymphatic drainage and arm bandaging of the women who require it, is performed. After the exercises, there is a so-called "therapeutic conversation", in order to stimulate the union and friendship between the patients and the professionals who care for them.

Inclusion criteria were: attending rehabilitation group regularly, or have attended at least half 
of the sessions scheduled for the last three months prior to the start of data collection and have had a mastectomy, in order to give homogeneity to the sample and minimize possible biases in the survey. Exclusion criteria were; present difficulties in orientation, in time and space and cognitive difficulties in relation to questions directed to them, which would prevent participation in the study.

Data were collected between May and July 2011, through semi-structured interviews and focus groups. In the first stage, the medical records of women who matched the inclusion criteria were separated. Firstly, the names of women who attended in the last three months were found were verified in the attendance book, totaling 16. Next, we investigated if these records matched the second inclusion criterion, which excluded seven women. One participant had not completed all the steps, due to not attending the focus groups. Thus, at the end, eight women participated.

The invitation to participate in the survey was carried out in the days and hours of operation, or other days and times, by phone, by the first author, who had participated in the multidisciplinary team of the group, which facilitated contact and interaction with women.

A form with two pieces was used: the first containing personal, sociodemographic details about the women's treatment which was populated from the information extracted from medical records, for the purpose of characterizing the sample data. The second included questions about the perception of the benefits and barriers to participation in rehabilitation groups, which were built from the dimensions of the Health Belief Model, in order to guide both semi-structured interviews and focus groups. The instrument was submitted to health professionals with expertise in rehabilitation groups, which promoted adjustments to the suggested changes. After this process, a pilot test was conducted with women with breast cancer in order to validate the instrument's content, which lead to minor adjustments for clarity in the presented language.

The triggering questions which were used included: tell me how you learned of the existence of the rehabilitation group and why you came to the service. What are the factors that motivate or discourage you to attend it and what facilitates and hinders your attendance?

In the second stage, there were three focus groups; a technique to generate in-depth information, through group interaction, to help interpret the object of study. ${ }^{12}$ The meetings took place in the Qualitative Research Laboratory of the Nursing Institution, which has full acoustic and imaging equipment (microphones and cameras) and an airy, well-lit environment. The sessions lasted an average of an hour and a half each, always with eight members, conforming to the recommendation that the groups have up to twelve people. ${ }^{12}$

Each session included a coordinator / facilitator skilled in the art, the first author led the group's activities. Initially, the researcher presented and explained the purpose of the research. A moderator took charge of the recordings and the comfort of the participants.

In a third stage of the research, the individual interviews were performed, face to face interviews with all participants were conducted in their homes after the end of the collection phase in the focus groups. The same questions of the focus groups were repeated in the individual interviews in order to give the possibility for each additional participant the information they deemed necessary.

For the narrative fidelity, some adjustments to the language were made, seeking to keep the characteristics of individual expressions and associating impressions recorded in the notebook which were essential to assist in analysis.

Data collection was completed at the time that the empirical data provided an understanding of the subject matter. Participants were identified by the letter " $E$ " followed by the Arabic numeral in the order which the invitations were made. To identify the data collection technique, the letters "FG" were used for focus group and "IN" for interviews.

The resulting contents of the data collection was transcribed in full; thematic content analysis was used for the interpretation of details. ${ }^{13}$ The first step was a thorough reading of the transcripts where significant statements were identified for the subject matter. After, coding was performed according to the pre-defined dimensions of the Health Belief Model theoretical framework of perceived benefits and barriers. The third step was the identification and appointment of subtopics or themes to undertake data analysis. Subsequently, the phase of interpretation of dialogues from other studies. Thus, the categories emerged: "Benefits of returning to daily activities, obtaining information and sharing experiences" and "institutional and personal barriers such as limiting factors for membership and participation in the rehabilitation group." 
All participants signed the Informed Consent Form, respecting the ethical procedures contained in Resolution 196/96. The development of the research project was approved by the Ethics Committee of the Nursing School of Public Institution of Education, in report number 1200/2010.

\section{RESULTS}

The average age of participants was 60 years of age (54-67 years old). The prevalent marital status was married (five participants); schooling ranged from completed higher education (one participant) to incomplete primary education (two participants). The occupation most referred to was housewife (four participants) and quadrantectomy (four participants) was the most reported surgery. All underwent neoadjuvant treatments. The time of participation in the group ranged from six months (one participant) to five years (four participants).

\section{Benefits of returning to daily activities, ob- taining information and sharing experiences}

Regarding the amplitude of the benefits related to participation in the rehabilitation group, women exposed the improvement of physical performance after obtaining guidance, once withheld, and the ability to return to daily activities.

[...] for me, the best thing is that we are able to return to taking caring of our things, the house, ourselves, we have a better disposition. (E5; FG).

[...] I really like the exercises because I felt that after I started to do them, I improved my arm movements, because when we do surgery [mastectomy] we think that we have to be careful with the arm, no one warns us about anything (E7; IN).

No one [health professionals] explained anything right to me, it was only after I came to join the group that I understood my illness and surgery, because my arm was heavy and it was getting worse if I didn't exercise it. (E8; FG).

From the reports, it is observed that they perceive the participation in the group as a way to meet their expectations with regard to solving many of their problems, especially those related to the doubts that many of them have regarding the physical rehabilitation process and re-adaptation to their daily lives and social life.

[...] it's very good here in the group, because all your questions are answered, so you are not left thinking nonsense (E8; FG).
It is very good to know that we can count on you to remove our doubts. I myself, when I have something that is bothering me, I feel good when I come here and you guide me (E4; FG).

In this way, by expressing the perceived benefits of membership in the group, satisfaction was noticed when they spoke of the role of the multidisciplinary team.

[...] I really enjoyed the whole team. You feel happy to be welcomed, that your concern has the attention of all the professionals (E6, IN).

[...] I needed a lot of physical therapy. I got here and found everything I needed. The nurses were very welcoming to me and the students filled in all the information to understand my case and to check how my scar was; they were very thoughtful (E4; FG).

It is observed that, in oncology care in, the fragility emanating from each patient and professional commitment to meet the needs of this, builds a committed relationship, permeated by solidarity, by tenderness and mutual attachment, whose meanings cease being individual, creating a social sense.

[...] professionals are very attentive and care about our well-being; I feel welcome here (E2; FG).

[...] I think that professionals really like to work with us, because they don't do it out of obligation, they do so because they like it, I think (E3; IN).

Participants also revealed that when the adaptation phase elapsed, they were able to see, the psychosocial benefits of their participation in the service as members, like experiencing with other people who also carry a stigmatizing disease which helped them to feel equal and to share experiences, feeling comforted by the group experience.

[...] here I never feel alone, I have friends that I can vent to (E4; GF).

I found participation in the group very valuable because we stay with people like ourselves, with the same problems, you see that you are not alone (E5; IN).

Here it seems that I feel closer to an identity. Being close to those who experience the same problem as us is good (E7; FG).

By sharing their experiences, women feel motivated to help each other. The benefits generated in these meetings can provide a huge energy to its members that can be brought to their living space, contributing to their rehabilitation and recovery both physically, social and psychological. 
[...] for me, it is really good be here, you talk about your problem and listen to your friend's problem. We create a friendship, that even when I'm at home, I think about the other person's problem, if it is better already or not. You have the opportunity to say what you are feeling and what you need. Here, everyone helps (E3; FG).

Some respondents commented that the first time they came into contact with the group and with the other women; they felt strange in the environment, which can be attributed to the stigma attached to breast cancer. When they found women with breast cancer smiling and willing, this caused them to feel strange.

[...] the first time I came here, it was strange, everybody was cheerful. I thought how is it possible?! I was even nervous, but then I saw it was a place to overcome things (E3; IN).

[...] At the beginning, it was strange to see all the people full of joy of, but then we could see that it is because the group makes us get better (E6; FG).

Many of the participants said that from that moment, they invested longer in taking care of themselves, which relates to knowing more about the disease and to be disciplined with the care of your health; as well as the group participation takes on a more central position in their living spaces, because in the past this time was dedicated to other tasks such as taking care of family and home, but now taking care of their well-being is fundamental.

[...] the group made me well, you know, before I did not take time for me, I was just thinking about taking care of the home and my husband, today I take care of myself (E7; IN).

[...] nowadays I don't take anything too seriously, I worry mostly about myself, I take care of myselfbecause I faced much worse, cancer (E3; FG).

In this category, the women's comments show to be equivalent both in the interviews and in the focus groups, complementing each other. Also there was no inhibition by the deponents, speaking in public, together with the other participants and researchers or individually. These observations are important to demonstrate how women feel comfortable with the group experience and with the active researchers in the service, which shows that the interaction with health professionals and other patients favors the link with the health service, acting as a primary benefit which assists in adherence to rehabilitation.

\section{Institutional and personal barriers as limiting factors for membership and participation in the rehabilitation group}

The women identified barriers to group participation, group rehabilitation, the adherence of activities and to the guidance provided. Thus, when they are asked about what they thought of the service routines, they expressed that there could be more days of care, to diversify and to facilitate attendance.

[...] I depend on my husband to bring me here to the group. So, I prefer to go in the afternoon, because then he isn't busy. But if we are absent for some reason, there is only service on the next Thursday and it is bad for me because I do drainage (E1; FG).

[...] I try and attend the day care because I know it's the best day and time for the majority of people; but the tricky thing is you have only one option. If they had more days of service, it would be easier (E5; IN).

The demands of the service are also present when the women report the need for more physical space to accommodate all participants and give greater dynamism to the activities.

[...] I like the number of people; we do not feel alone here, we feel that we are all in the same boat. But sometimes, it's kind of hard to do all the activities because of the space (E2; FG).

[...] It's a good number of people, one helps the other. Sometimes your question is the same as your colleague and there are a lot of people to clarify things, but when you have more people, sometimes it gets a little tight (E8, IN).

When we asked the interviewees about the regularity of their participation and what are the reasons for absences, the need for time to have to attend the group's activities and to be willing was recognized as a major barrier.

[...] there are days that I do not I come because I live alone after having been widowed and often, I am discouraged, unwilling, but after we are absent, we see that it was better to come, we feel the need (E2; IN).

Sometimes we are absent because we are discouraged, tired, because it only takes time away from work and so we lack willpower (E6; FG).

Another factor considered relevant by women which hindered the adherence to the group rehabilitation of the program is the commitment to housework.

We have greatly improved this part I will tell you, but there are days that we get distracted both with home 
chores that when we look at the time and it's too late to go to the group (E6; GF).

There are days when I work at home and I'm tired and discouraged to go to the group (E1, EN).

In this category, there was also a cohesiveness in the statements arising from both: the focus groups, and the interviews. The participants were at ease to discuss about possible barriers of participation in the rehabilitation group in both situations. The findings revealed that there are major obstacles in the adhesion process, both arising from personal conditions of women, and from aspects of the service. These complicating factors need to be worked out by the health team with a view to increasing adherence to the proposal of the rehabilitation group, consisting of the full rehabilitation of its participants.

\section{DISCUSSION}

Rehabilitation after treatment of breast cancer, through the adoption of a healthy lifestyle, has the potential to generate physical, psychological and an overall increase in quality of life. A study carried out in Iran in $2010^{14}$ comparing the quality of life of breast cancer survivors who received rehabilitation (physical therapy, education and individual counseling) and another group with isolated medical assistance, concluded, after evaluating 57 women, that in patients which rehabilitation therapy was possible, there was a gradual improvement in the overall quality of life, with minimal changes observed in the control group.

Another study, which evaluated the effects of physical activity for breast cancer survivors, through meta-analysis of randomized controlled trials found that physical exercise is associated with improvements in posture, pain, fatigue, depression and in quality of life and positive psychological results. ${ }^{15}$

A study ${ }^{16}$ that evaluated the prospects of mastectomy patients on secondary functional limitations in the treatment of breast cancer, including upper limb movement restriction, lymphedema, fatigue, weight gain and pain found that many women complained of misinformation about these adverse events and the possibility of persistence of the end of therapy. These findings corroborate the results of this research which identified the lack of guidance by health professionals, and has proved one of the reasons for the search of help through rehabilitative groups.
Therefore, the provision of information emerges as a primary outcome of this study, by generating benefits due to the participation in rehabilitation groups, which allowed women to obtain clarification of doubts and uncertainties affecting the diagnosis and treatment of breast cancer and provided greater participation in service, as found in the professional explanations, answering their questions which motivated them to continue in the rehabilitation process.

It is known that the experience of women with breast cancer is complex, affecting all aspects of life during and after treatment. ${ }^{17}$ Thus, the development of work in groups of multidisciplinary team can contribute to the return of patients to their daily lives and their activities.

The rehabilitation process depends largely on the formation of a multidisciplinary team that works seamlessly and keeps a good relationship with breast cancer patients and their families. Staff should be available to provide information about the disease and its possible complications and be prepared to accept this patient in their physical and emotional difficulties and include them into fellowship with other women who go through similar experience. ${ }^{7,9}$

These results will meet the assumptions of the Health Belief Model which claims that the perception of the benefits works as a motivational factor for the systematic participation and adherence to care programs for the health of the individual. ${ }^{11}$

The determining factors for adherence to rehabilitation programs are mainly related to trust, acquired by a woman, with the professional involved in her care, as she finds support and commitment to the rehabilitation process. ${ }^{9}$

In this context, nurses play a key role, since they are involved in the direct care and can pass the needs of customers to team members, so that the expected results are achieved. ${ }^{5}$ This is also in this study, when women demonstrated in their discourses that the nursing professionals welcoming was essential for them to stay in the group.

Living with other women who were diagnosed with breast cancer generated a link between women and can be understood as a key strategy in reducing negative feelings and stigmatizing disease. In addition, active listening developed between them began a collaborative process in their own recovery, strengthening friendship and minimizing feelings of rejection or their withdrawal. ${ }^{8}$ 
In another survey on the use of groups for women with breast cancer, the authors said that experience in groups consisting of people who go through similar problems, provide an experience that can develop extremely beneficial results for the rehabilitation of patients, being considered a factor for both curative aspects and for the behavioral change. ${ }^{8}$

In this study, the receptivity and the subsequent coexistence with other women and with professionals provided group interaction, which, confirming the assumptions of Health Care Model, led to behavior change and adherence to guidelines, overcoming potential barriers that could be created by feelings of loneliness and social isolation.

The first time at the group, it seems they are forced to face the disease again; making concepts of cancer as a deadly disease emerge. However, when they realize that cancer was present in the lives of other women, they gradually felt part of the group and started to consider it as a place of overcoming, which enabled them to visualize more benefits than barriers to adhesion of the proposed activities.

Thus, it is understood that women are aware of the seriousness of cancer, resuming their lives, seeking to know more about the disease and its consequences, trying to be more understanding, patient and disciplined in relation to the care of their health and, thus, the development of healthy habits taking a more central position in their lives, contributing to the recovery of their health.

Patient satisfaction, revealed through their health behavior, in relation to care for their recovery after a grievance, is determined by the interaction between their expectations, or beliefs about the disease, its severity and characteristics of the care received. These include items related to the access to services, the costs, the nature of the facilities and care, as well as their continuity. ${ }^{10}$

It is believed that all of these characteristics, orientations and activities provided in the group, identified by the study participants, greatly influenced the adherence to behaviors and positive attitudes towards rehabilitation.

Thus, women have developed a relationship which sought to comply with the structures that make up the group work process. These compositions include the operating rules, as the days, times and site structure.

A study conducted in Mexico showed that despite the benefits of a group, users can mention barriers such as lack of continuity in the activities, meetings schedules and the difficulty of traveling to attend the sessions. The survey revealed the need for the group to rearrange the actions to meet the needs of patients and ensure their participation to help them in their rehabilitation process. ${ }^{18}$

The participants of this study confirmed, expressing criticism and suggestions, that they considered the space offered by the service as insufficient, due to the increasing number of participants. Thus, it is considered that, despite the attendance being assiduous and women identifying several benefits to join the activities undertaken in the group, adaptations for quality care are necessary, by providing greater aids to motivate them to take action and participate in the rehabilitation service.

Women expressed the need for time to attend the meetings and to be willing to exercise as barriers to participation in the rehabilitation group. These results are consistent with a literature review in which the authors investigated the adherence to practicing exercises for functional rehabilitation of women with breast cancer and stressed the need for them to devote time for themselves and, if not, the activities incorporated into their daily lives would be affected. ${ }^{9}$

Women with responsibilities of household tasks is also a determining factor for the performance or nonperformance of any further activity. This difficulty reflects the caregiving role, historically directed at females. Even nowadays, due to a strong cultural components, women have difficulties in prioritizing other activities other than domestic and related duties of the home. ${ }^{19}$

The guidelines undertaken in the rehabilitation group can be a key point for women to recognize the importance of adhering to the activities and strive to promote changes in behavior and lifestyles. According to the Health Belief Model, the change in behavior makes caring for themselves attractive, mobilizing it to a central positions in their lives. ${ }^{13}$

\section{CONCLUSION}

Participation in the rehabilitation group was influenced positively by factors such as perceived benefits of physical improvement, access to information, involvement with health professionals and other members of the group. The lack of time and willingness, domestic chores and family responsibilities constituted as the main personal barriers 
to follow the rehabilitation program and the need for more physical space and days of care services, as the largest institutional barriers.

Analyzing the participation of women with breast cancer in the service involved the observation of several factors that were beyond the checking of attendance at sessions, the necessity of understanding the perceptions that permeate the search for the recovery of a disease surrounded by stigmas and a long and painful treatment. Thus, actions are needed to strengthen the facilitating factors and mitigate barriers, brining patients and professionals together.

Therefore, we understand that we must evaluate the quality of rehabilitation services from the perspective of the users to establish goals and set priorities, focusing on the comprehensive rehabilitation, requiring the creation of new spaces and multidisciplinary teams, considering the complexity of attention to cancer patients.

\section{REFERENCES}

1. Vendrusculo-Fangel LM, Panobianco MS, Kebbe LM, Almeida AM, Gozzo TO. Quality of life and daily activities performance after breast cancer treatment. Acta Paul Enferm [Internet]. 2013 Jan-Mar [cited 2015 Nov 15]; 26(1):93-100. Available from: http:/ / www. scielo.br/pdf/ape/v26n1/en_15.pdf

2. Mistura C, Carvalho MFAA, Santos VEP. Mulheres mastectomizadas: vivências frente ao câncer de mama. Rev Enferm UFSM [Internet]. 2011 [cited 2015 Nov 15]; 1(3):351-9. Available from: http://cascavel.ufsm. $\mathrm{br} /$ revistas/ojs-2.2.2/index.php/reufsm/article/ view/2943/2384

3. Furlan MCR, Bernardi J, Vieira AM, Santos NCC, Marcon SS. Percepção de mulheres submetidas à mastectomia sobre o apoio social. Ciênc Cuid Saúde [Internet]. 2012 jan-mar [cited cited 2015 Nov 15]; 11(1):66-73. Available from: http:/ / www.periodicos. uem.br/ojs/index.php/CiencCuidSaude/article/ view $/ 18860 /$ pdf

4. DeLisa JA. A history of cancer rehabilitation. Cancer [Internet]. 2001 Aug [cited 2015 Nov 15]; 92 (suppl 4):970-4. Available from: http:// onlinelibrary.wiley.com/doi/10.1002/1097$0142(20010815) 92: 4 \% 2$ B \% 3C 970 : : A ID CNCR1408\%3E3.0.CO;2-T/pdf

5. Andrade LT, Araújo EG, Andrade KRP, Soares DM, Cianca TCM. Papel da enfermagem na reabilitação física. Rev Bras Enferm [Internet]. 2010 [cited 2015 Nov 15]; 63(6): 1056-60. Available from:http:/ / www. scielo.br/pdf/reben/v63n6/29.pdf

6. Petersson LM, Berglund G, Brodin O, Glimelius B, Sjoden PO. Group rehabilitation for cancer patients: satisfaction and perceived benefits. PEC J[Internet]. 2000 Jun [cited 2015 Nov 15]; 40(3):219-29. Available from: http://www.pec-journal.com/article/S07383991 (99)00102-0/pdf

7. Caetano EA, Panobianco MS, Gradim CVC. Análise da produção científica nacional sobre a utilização de grupos na reabilitação de mastectomizadas. Rev Eletr Enferm [Internet]. 2012 [cited 2014 Out 12]; 14(4):96573. Available from: http://www.revistas.ufg.br/ index.php/fen/article/view/17112/13362

8. Soster CA, Neumann SS, Cardoso C. Coesão de um grupo de apoio a mulheres com câncer de mama. Rev Psicol Foco [Internet]. 2013 jul [cited 2015 Jan 15]; 5(5):116-33. Available from: http://revistas. fw.uri.br/index.php/psicologiaemfoco/article/ view/1106/1594

9. Sant'anna DK, Almeida V, Petito EL, Gutiérrez MGR. Adesão à prática de exercícios para reabilitação funcional de mulheres com câncer de mama: revisão de literatura. Cienc Enferm [Internet]. 2010 [cited 2015 Nov 15]; 16(1):97-104. Available from: http:/ / www.scielo.cl/scielo.php?pid=S071795532010000100011\&script=sci_arttext

10. Rosenstock IM. The health belief model and preventive health behavior. Health Educ Monographs [Internet]. 1974 [cited 2015 Nov 15]; 2(4):354-87. Available from: http://heb.sagepub.com/content/2/4/354.full.pdf

11. Rosenstock IM. The health belief model: explaining health behavior through expectancies. In: Glanz K. Health behavior and health education: theory, research and practice. San Francisco (US): Jossey-Bass; 1990; p. 39-62.

12. Gatti BA. Grupo focal na pesquisa em ciências sociais e humanas. Brasília (DF): Liber, 2005.

13. Bardin L. Análise de conteúdo. Rio de Janeiro (RJ): Edições 70, 2004.

14. Poorkiani M, Abbaszadeh A, Hazrati M, Jafari P, Sadeghi M, Mohammadianpanah M. The effect of rehabilitation on quality of life in female breast cancer survivors in Iran. Indian J Med Paediatr Oncol [Internet]. 2010 Oct-Dez [cited 2015 Jan 15]; 31(4):105109. Available from: http:/ / www.ncbi.nlm.nih.gov/ pmc/articles/PMC3089917/

15. Fong DYT, Ho JWC, Hui BP, Lee AM, Macfarlane DJ, Leung SK, et al. Physical activity for cancer survivors: meta-analysis of randomized controlled trials. BMJ [Internet]. 2012 Jan [cited 2015 Jan 15]; 344-70. Available from: http://www.bmj.com/content/344/ bmj.e70.full.pdf + html

16. Binkley JM, Harris SR, Levangie PK, Pearl M, Guglielmino J, Kraus V, et al. Patient perspectives on breast cancer treatment side effects and the prospective surveillance model for physical rehabilitation for women with breast cancer. Cancer [Internet]. 2012 Apr [cited 2015 Jan 15]; 118:2207-16. Available from: http:// onlinelibrary.wiley.com/doi/10.1002/ cncr.27469/epdf 
17. Rosa LM, Radünz V. Women with breast cancer: from symptoms to adjuvant treatment. Text Context Nursing. 2013 Jul-Sep [cited 2015 Jan 15]; 22(3):71321. Available from: http:/ / www.scielo.br/pdf/tce/ v22n3/en_v22n3a18.pdf

18. Tejada-Tayabas LM, Lugo MJR. The role of mutual support groups for the control of diabetes in a Mexican city: achievements and limitations from the patients' perspective. Health [Internet]. 2014 Aug [cited 2014 Sep 22]; 6:1984-93. Available from: http://dx.doi. org/10.4236/health.2014.615233

19. Caetano EA, Gradim CVC, Santos LES. Câncer de mama: reações e enfrentamento ao receber diagnóstico. Rev Enferm UERJ [Internet]. 2009 [cited 2015 Jan 15]; 17(2):257-61. Available from: http:/ / www.facenf.uerj.br/v17n2/v17n2a21.pdf 